\title{
A Research of Embroidery Industry in Medieval Bengal $\left(13^{\text {th }}-17^{\text {th }}\right.$ Century $)$
}

\author{
Abdul Motleb Shaikh
}

\begin{abstract}
The article essays at bringing together the knowledge of embroidery productions in medieval Bengal as derived from various sources such as local, Persian and travellers account. An attempt has been made to identify embroidery productions and its demands in internal and external markets as well as impact on economic life of the people of Bengal. About the embroidery industry during the period under study still exists a gap requiring an inquisitive research which will reveal the exact or near to exact scenario with respect to these aspects of non-agrarian economy so, this study is an attempt to answer such questions, mainly on the evidences provided by foreign traveller's records, Persian sources, and other contemporary' records.
\end{abstract}

Keywords- Medieval Bengal; embroidery; industry; economic life and market.

\section{INTRODUCTION}

Among the industries that flourished in Bengal during the period under study, embroidery industry occupies the most important position. Bengal has achieved great fame for this industry since ancient period. We have evidence from Periplus of the Erythraean Sea written by a Greek sailor in the first century AD who refers to the muslin of the finest quality exported from Bengal. ${ }^{1}$ About embroidery productions there still exists a gap requiring an inquisitive research which will reveal the exact or near to exact scenario with respect to these aspects of non-agrarian economy. So, this study is an attempt to answer such questions, mainly on the evidences provided by foreign traveller's records, Persian sources, and other contemporary' records

\section{EMBROIDERS}

Two types of embroidery work were practiced in medieval Bengal. The first consisted mostly of quilted bedspreads worked with pictorial designs in yellow tussur silk made in the Hugli region. Second the needlework covers of almost every square inch of the ground was embroidered muslin fabrics from Dacca. ${ }^{2}$ This needlework was further of two types, coloured silk embroidery in chain -stitch, and 'white embroidery', maybe corresponding to what later came to be known as Dacca chikan embroidery (cotton worked on cotton). ${ }^{3}$ Mention of shifis (a kind of chemise worn by women) besides, the above is worth mentioning being used by women. Portuguese are also credited for encouraging the embroidery works of Bengal. ${ }^{4}$ Various types of designs used such as hunting scenes with European figures and illustrations either of Old Testament stories. Besides these European styles Indian Vaishnava representations also used such as of the Great Flood, Matsya or fish, etc. ${ }^{5}$ The silk embroidered worked in Dacca were

Revised Manuscript Received on April 12, 2019.

Dr. Abdul Motleb Shaikh, Research Scholar, CAS. Department of History, AMU, Aligarh. (E-mail: abdulmotlebshaikh@gmail.com) generally used Hindu and European style rather than Islamic style. Besides these, the designs were birds, animals, flowers, and decorative motives borrowed from both Indian and European style due to the Portuguese influence.

Bengal had a reputation both in design and weaving of cotton textiles in medieval times and it was the basis of trade link between Bengal and foreign countries like Asia, Africa, and Europe. ${ }^{6}$ Sulaiman the $9^{\text {th }}$ century Arab traveller while describing the Bengal textile says that it was extremely a fine fabric. ${ }^{7}$ Subsequently, in the late 13th century, Marco Polo also referred the commercial importance of Bengali fabrics. ${ }^{8}$ Between 1415 and 1432 several Chinese diplomats had visited Bengal and also praised textiles of Bengal such as fine cotton cloths (muslins), rugs, veils of various colours, gauzes (pers, shana-baf), material for turbans, embroidered silk, and brocaded taffetas. ${ }^{9}$ These Bengali fabrics were in great demand in China and exported to China based on colour and quality known as pi-pu or bibu (a woven fine and white cloth), man-che-l' I or manzheti (a coloured Calico), sha-na-pa-fu or shanabafu (Persian's shanbaft or crepe), $k$ 'i- pari-lei-ta-li or xinabailedali (or jhanbartali, a fine muslin), sha-ta-eul or chaotaer (a fine cotton cloth), ma-hei-ma-lei or moheimoluo (cotton velvet). $B i b u$ was an evenly woven fine white cloth used most likely for lower part of body. manzhet was available in yellow colour or ginger-yellow colour. Xinbailedali was used as turban Chaotaer's Moheimoluo thick velvety. We find the reference to other three fabrics also. They were sahala or sakalat (light woollen texture) and zhefu (Arabic's suf), a woollen cloth (blanket type) and hei-dalibu, a black coarse cloth. $^{10}$

A century later Ludovico di Varthema, who had visited Bengal in the first decade of the $16^{\text {th }}$ century and remarks the importance, that, "Fifty ships are laden every year in this place with cotton and silk stuffs.... These same stuffs go through all Turkey, Syria, Persia, Arabia Felix, Ethiopia, and throughout India."11 Bengal had produced about twenty varieties of cotton cloth with different colours. ${ }^{12}$ He further says that mamuna, duguza, chautar, topan, and sanabafos were very famous. ${ }^{13}$ Referring by Varthema, famous twenty varities of Bengali textile four of which among them were chautares, beatilhas and bierames, has been properly identified by an eminent scholar Irfan Habib with certain varities of textiles. ${ }^{14}$ Consequently, Tome Pires also remarked that the textiles of Bengal exported to foreign countries through the Indian Ocean, and Bengal was one of the major textile production centres. ${ }^{15}$ The exports of Bengali textiles were also great demand in Malacca also. ${ }^{16}$ 
Portuguese traveller Duarte Barbosa who had visited Bengal in the first half of the $16^{\text {th }}$ Century remarked that, different kinds of cotton cloths which were almost similar to those referred to earlier by Varthema. Praising the textiles of Bengal he says,

"In it are woven many kinds of very fine and coloured clothes for their own attire and other white sorts for sale in various countries. They are very precious, also some of which they call countries. They are very precious, also some of which they call estravantes, a certain sort, very thin kind of cloth much esteemed among us for ladies' headdress and by the Moors, Arabs, and Persians for turbans. Of these great stores is woven so much so that many ships take cargoes therefore for abroad, others they make called memonas, duguazas, chautares, sinabafes, which latter two are the best of all, and the Moors held them the best for shirts. All these sorts of cloth are in pieces, each one where of contains about three and twenty or four and twenty Portuguese yards. Here, they are sold good cheap; they are spun on wheels by men and woven by them."17

\section{ANALYATICAL RESULTS \& DISCUSSIONS}

The terms such as estravantes, memonas, duguazas, chautares, sinabafes and beatilha have tentatively been identified with irband, malmal, dugazi cloth, chadar, sinaband and butidar. M. Caesar Fredricke and Ralph Fitch also have referred to the manufacture of textle. Ralph Fitch visited the city of Sonargaon where he found the best and finest cloth made of cotton. ${ }^{, 18}$ Prising the Bengali textiles Barani mentions that Bard was another kind of textile sold very low priced in Lakhnauti. ${ }^{19}$ Abul Fazl also mentioning the quality of the textiles of Bengal and viewed that, 'The Sarkar of Barbakabad products, a fine quality of textile called Gangajal (Ganges water)'. He further says, "The Sarkar of Sonargaon also products a kinds of muslin very fine and in great quantity". ${ }^{20}$ Besides coton fabrics, Bengal was also famous for jute fabrics productions. The contemporary Bengali literature shows that jute fabrics like patneta and pater pachra were made during this period. According to Abul Fazl the jute cloth onely produced in the Sarkar of Ghoraghat. ${ }^{21}$ Bengal, thus, had been a flourishing state of textile manufacturing, where all kinds of cotton clothes were produced. Mention has already been made of headdress or scarf, turban, chadar or sheets, handkerchiefs, shirts and shawls were available during this period. The Sonargaon, Satgaon, Barbakabad and Ghoraghat were the chief centres of cotton fabric in Bengal. ${ }^{22}$

An infrequent Maithili work of the $14^{\text {th }}$ century, known as Varnaratnakara written by a Maithili Brahmin Jyotirisvara, has given a long list Bengali textile. It references about thirty types of textiles, additional twenty varieties of desiya vastra or country stuff, thirteen of nirbhusan vastra or plain fabrics and fourteen of neta or fine stuff. ${ }^{23}$ It also gives as many as seventeen varieties of vastra-griha or enclosures made of textile. But it is very problematic to have an exact idea or meaning of the terms used for various types of fabrics. Despite this, the two terms such as masahari and moja can easily be understood. The term masahri is alike to musahri which is described by Jyotirisvara as fitted to the bed of a Prince. This shows that musahri or musari meant

here mosquito net. The second one is moja was most likely stocking, a hosiery produce generaly used by people. These two items of textile products were only known during the beginning of the $13^{\text {th }}$ century. ${ }^{24}$ Varnaratnakara of Jyotirisvara also gives very important information that the artisans' class of people who were involved the textiles productions. $^{25}$

It is very surprising to note that there is no information in any foreign traveller's account regarding the class of the people to involve in the textile production. Though the Barbosa remarks that cotton, produced in the fields, was spun on wheels and then it was woven and made into fine fabrics, but he was also silent who were these men engaged in spinning and weaving the textiles productions. But Varnaratnakara of Jyotirisvara had mentioned that the last decade of the $13^{\text {th }}$ century or by the beginning of the $14^{\text {th }}$ century artisans class of people appeared. The work of weaving was done by a group or caste of people who were known as Jola or Jolha, as is exposed by another Maithili works named Brahmavaivarta Purana which was written in the end of the $15^{\text {th }}$ century, they subsequently considered as a 'Manda jati' and were called dhunia or cotton carders. ${ }^{26}$ Varnaratnakara of Jyotirisvara and Brahmavaivarta Purana shows that the artisans class, i.e. jola or jolha and dhunia or cotton carders were played an important role in the foundation of cotton crafts production during the beginning of the $13^{\text {th }}$ century in Bengal. Before the $13^{\text {th }}$ century in Bengal the Brahmans were degrading the social status of jolas and other weaver class due to the Brahmans restricted the social mixture, as a result, this social degradation had a bad impact and also on their profession all this lead to the low textile production. But with the beginning of the Turkish rule, the artisans class becomes free from the social restriction and enhanced the textile productions, they came to the fold of Islam to get rid of their injustices meted out to them on account of being inferior castes. As we come to know that, during the Sultanate period, cotton ginning became an independent profession. As cotton carding, spinning and weaving were also done by the weavers, the increase of cotton cloth during the period of my review gave an impetus to their profession, this lead to increase in the production of cotton crafts. The manufacturing of cotton and silk fabrics made room for the rise of other works such as embroidery and dyeing. ${ }^{27}$

\section{REFERENCES}

1. ${ }^{1}$ Wilfred H. Schoff, The Periplus of the Erythraean Sea Travel and Trade in Indian Ocean by a Merchant of the first Century, $2^{\text {nd }}$ ed., Oriental Reprint Corporation, New Delhi, 1974, p. 252

2. ${ }^{2}$ John Irwin \& P.R. Schwartz, Studies in Indo- European Textile History, Calico Museum of Textile, Ahmedabad, India, 1966, p. 47

3. ${ }^{3}$ Ibid. p. 47

4. ${ }^{4}$ Ibid.

5. ${ }^{5}$ Ibid., p. 48

6. ${ }^{6}$ Edward Baines, History of the Cotton Manufacture in Great Britain, H. Fisher, R. Fisher, and P. Jackson London, 1835, p. 4 
7. ${ }^{7}$ Elliot and Dowson, The History of India: As Told by its Own Historians, Vol. I, Trubner and Co., London, 1867, p. 361

8. $\quad{ }^{8}$ Henry Yule and Henri Cordier, trans. and eds. The Book of Ser Marco Polo. 3rd. Vols. 2, Philo Press, Amsterdam, 1975, p.115

9. ${ }^{9}$ W.W. Rockhill, 'Notes on the Relations and Trade of China with the Eastern Archipelago and the Coast of the Indian Ocean during the Fourteenth Century,' Part II , Vol. 16, No. 1, T'oung Pao, Second Series, Brill, 1915, pp. 61-159

10. ${ }^{10}$ P.C. Bagchi, 'Political Relations between Bengal and China in the Pathan Period,' op.cit., pp. 114-15 Haraprasad Ray, Trade and Diplomacy in India-China Relations: A study of Bengal during the $15^{\text {th }}$ Century, Radiant Publishers , New Delhi, 1993, pp. 83-92

11. ${ }^{11}$ John Winter and George Percy Bedger, eds. The Travels of Varthema, Hakluyt Society, London, 1963 , p, 212

12. ${ }^{12}$ Duarte Barbosa, The book of Duarte Barbosa, Vol., II, tran. M.L. Dames, Hakluyt Society, London, 1921, pp. 145-146

13. ${ }^{13}$ John Winter and George Percy Bedger, eds. The Travels of Varthema, op.cit., p, 212

14. ${ }^{14}$ Iran Habib, 'Economic History of Medieval India, 12001500,' Vol. VIII, Part I, General Editor, D.P. Chattopadhyaya, PHISPC, Pearson, Delhi, 2011. pp. 90-91

15. ${ }^{15}$ Tom Pires, The Suma Oriental of Tome Pires, An Account of the East, From the Red Sea To Japan, written in Malacca and India in 1512-1515, Vol. 1, eds. and tr. Armando. Cortesao, Asian Educational Services, New Delhi, 1944, pp.89, 92. Tome Pires mentioned that "A junk goes from Bengal to Malacca once a year, and sometimes twice. Each of these carries from eighty to ninety thousand cruzados worth. They bring fine white cloth, seven kinds of sinabafos, three kinds of chautares, beatilhas, beirames and other rich materials. They will bring as many as twenty kinds. They bring steel, very rich bed-canopies, with cut-cloth work in all colours and very beautiful; wall hangings like tapestry .... These people sail four or five ships to Malacca and to Pase every year, and this is still done to a large extent. Bengali cloth fetches as high price in Malacca, because it is merchandise all over the East."

16. ${ }^{16}$ Ibid. pp. 88,92-93; Also see, Arun Dasgupta, 'Aspects of Bengal's Sea-borne Trade in the Pre-European Period,' Proceedings, Third History Congress , Dacca, 1973, p. 153

17. ${ }^{17}$ Duarte Barbosa, The book of Duarte Barbosa, Vol., II, op.cit., pp. $145-146$

18. ${ }^{18}$ Ralph Fitch, England's Pioneer to India and Burma. His Companions and Contemporaries, by J. Horton Ryley, Member of the Hakluyt Society T. FISHER UNWIN, PATERNOSTER SQUARE, LONDON, 1899, pp. 114, 164

19. ${ }^{19}$ Ziya- ud-din Barani, Tarikh- i- Firoz Shahi, f. 144a: for 'six tankas' as price given here, read 'six jitals,' the price actually given for the price of 'fine bard' in Barani's final version, p.310, Cf., Economic History of Medieval India, 1200-1500, PHISPC, New Delhi, 2011, p.90

20. ${ }^{20}$ Abul Fazl, Ain-i- Akbari, Vol. II, translated into English by Colonel H.S. Jarrett, Low Price Publications, Delhi, 2011, p. 136

21. ${ }^{21}$ Ibid.

22. ${ }^{22}$ Irfan Habib, An Atlas of the Mughal Empire, op. cit., Map. 11B

23. ${ }^{23}$ Joytirisvara Thakur, Varna- Ratnakar, ed. S.K. Chatterjee \& Babua Misra, Bib. Indica, Asiatic Society of Bengal, Calcutta, 1940, p. 205

24. ${ }^{24}$ W.W. Rockhill, 'Notes on the Relations and Trade of China with the Eastern Archipelago and the Coast of the Indian Ocean during the Fourteenth Century.' op.cit., pp. 61-159
25. ${ }^{25}$ Joytirisvara Thakur, Varna- Ratnakar, ed. S.K. Chatterjee \& Babua Misra, op.cit., p. 205

26. ${ }^{26}$ Varnaratnakara (quoted in) B P Majumdar, 'New Forms of Specialisation in Industries of Eastern India in the TurkoAfghan Period, PIHC, 1969, pp. 227-228

27. ${ }^{27}$ Joytirisvara Thakur, Varna- Ratnakar, ed. S.K. Chatterjee \& Babua Misra, op.cit., p. 205 